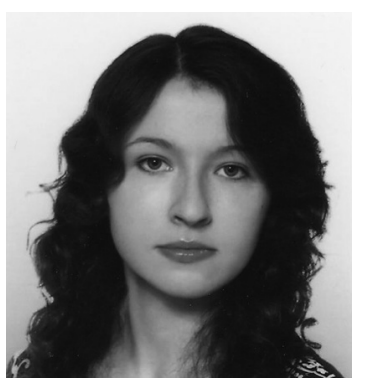

Katarzyna Trzeciak

Katarzyna Trzeciak - magister filologii polskiej i absolwentka podyplomowych Gender Studies na Uniwersytecie Jagiellońskim. Publikowała w internetowych pismach "Polisemia" oraz „E-splot". Interesuje się krytyką genderową oraz zagadnieniami transgresji w literaturze współczesnej. Opublikowała m.in. monografię Figury pożądania, figury pisania w wybranych nowelach Stefana Grabińskiego (2012). 


\section{Między retoryką Erosa a erotyką Tanatosa Czego pragnie bohater Na wzgórzu róż?}

\section{Rozkosz lektury/lektura rozkoszy}

1918 roku ukazał się drugi zbiór nowel (Na wzgórzu róż) zaistniałego już na polskiej scenie literackiej Stefana Grabińskiego ${ }^{1}$. Karol Irzykowski zastanawiał się przy tej okazji nad artystycznym idiomem autora, twierdząc, jakoby należało dla niego dopiero „szukać rubryki, tak bardzo jest on w naszej literaturze jakościowo odmiennym, przypadkowym"2. Jego wyjątkowość została natychmiast zestawiona z europejskimi autorami opowieści niesamowitych, których nazwiska wymieniano jednych tchem przy niemalże każdej recenzenckiej i krytycznej okazji ${ }^{3}$.

Właśnie oryginalność w dziedzinie fantastyki - tak precyzyjnie skonceptualizowana w teoretycznych wypowiedziach ${ }^{4}-\mathrm{z}$ której pisarz uczynił zasadniczy postulat swojej

\footnotetext{
1 Zaistniałego, acz pozostającego na marginesie zainteresowania. Grabiński debiutował w 1909 roku wydanym pod pseudonimem Stefan Żalny tomem Z wyjątków. W pomrokach wiary, jednakże ówczesna recepcja tego debiutu okazała się nieprzychylna. Co więcej, także późniejsi krytycy (w tym niezrównany jak dotąd monografista Grabińskiego, Artur Hutnikiewicz, powtarzający zresztą opinię Jerzego Eugeniusza Płomieńskiego przyjaciela i obrońcy twórczości autora Salamandry) deprecjonują znaczenie nowel z tego tomu. Gdyby jednak dzisiejszy badacz, wyposażony w narzędzia krytyki dekonstrukcyjnej czy genderowej, przyjrzał się chociażby konstrukcjom męskich postaci w opowiadaniu Podzwonne, być może stworzyłby interesujące warianty interpretacyjne dla zdeprecjonowanego zbioru.

2 K. Irzykowski, Fantastyka. Z powodu książki Stefana Grabińskiego „Na wzgórzu róż", [w:] idem, Wybór pism krytycznoliterackich, oprac. W. Głowala, Wrocław 1975, s. 563. Pierwdr.: "Maski” 1918, z. 32/33.

${ }^{3}$ Ergo nie ma chyba uzasadnienia dla repetycji tego chlubnego inwentarza w niniejszym szkicu. Odsyłam tu do najświeższego i kompetentnego zestawienia zagranicznych paralel, poczynionego we wstępie do antologii Maska śmierci. Opowieści niezwykłe, wyb., oprac. K. Bortnik, K. M. Choule, t. 2, Przemyśl 2010, s. 10 i n.

4 Zwłaszcza w Zagadnieniu oryginalności w twórczości literackiej, "Pamiętnik Literacki” 1925/1926, gdzie dokonuje szczegółowej typologii pojęć oryginalności, najwyżej ceniąc "oryginalność absolutną" Poego, Hoffmana, Norwida oraz (nie explicite) swoją.
} 
twórczości, stała się dość problematyczną „rubryką, w jaką wpisano postać autora Szalonej zagrody i jego niektóre (te łaskawie uznane przez krytyków) teksty. Większość dotychczasowych interpretacji i wzmianek o autorze pojawiło się w publikacjach zogniskowanych wokół problematyki polskiej literatury fantastycznej, dla której twórca L’Appassionaty wyznaczył pewne kierunki rozwoju i przez co zarazem teksty jego czytane są w większości wypadków kluczem historii niesamowitych ${ }^{5}$ (thrill story), a twórcy interpretacji wydają się szczególnie podatni na nastrojowy komentarz Irzykowskiego, który sugerował, że:

Opowieści jego [Grabińskiego] trzeba czytać późnym wieczorem zimowym, przy drwach płonących na kominku, gdzieś na wsi, gdy na dworze „zawierucha mokrym śniegiem dmie”, a wilki gdzieś wyją. Zamknąć radio i słuchać, czy wiatr okna nie otworzy i nie nawionie do izby czegoś nieokreślonego. Po czytaniu nie zasypiać, bo i tak zasnąć nie będzie można, lecz rozmawiać długo w noc o krańcach ziemi, o niebie i piekle, o naszych nieboszczykach i wspomnieć także o nieszczęśliwym za życia, tak utalentowanym czarnoksiężniku literackim [...] Stefanie Grabińskim ${ }^{6}$.

Liryczne westchnienie znanego krytyka (oczywiście, gdyby potraktować je zupełnie poważnie) zachęca do szczególnego, frapującego trybu lektury potrzebnego dla zinterioryzowania „uczucia wielkiego zdumienia, pełnego czci i uwielbienia zarazem zdumienia nad życiem i jego tajemniczością", które w poetyce konfesji własnych motywacji ideowych czynił Grabiński dominantą swojej twórczości. Tę tajemniczość życia można u niego widzieć poprzez nieustanną grę różnicowania pewnych powracających uparcie zagadnień, które prowokują konstruowanie przez czytelnika sensów wyzyskiwanych m.in. za sprawą posłużenia się nowatorskim instrumentarium interpretacyjnym ${ }^{8}$. Jeśli bowiem sam autor, olśniony cudownością rozmaitych przejawów życia, patrzący na świat „w zaraniu dni rozszerzonymi od zdumienia oczyma dziecka" ", pragnął odtworzyć swoim pisarstwem ludzką żądzę poznania, rozkoszny zachwyt nad interferowaniem wielopoziomowej rzeczywisto-

${ }^{5}$ Myślę tu zwłaszcza o komentarzach pojawiających się równolegle z wydaniami poszczególnych tomów nowel Grabińskiego. Wyczerpujący inwentarz recenzji z tego okresu sporządził w swojej monografii Hutnikiewicz (TLSG, s. 469 i n.). Uwzględniające możliwe ambiwalencje odczytań (sposób realistyczny i ekspresyjny) są dwie interpretacje utworu Spojrzenie, w których obok eksplikacji poprzez kategorie fantastyki niesamowitości pojawia się wyjaśnienie sytuacji bohatera w kategoriach obłędu i szaleństwa - zob. A. Smuszkiewicz, Zaczarowana gra. Zarys dziejów polskiej fantastyki naukowej, Poznań 1982, s. 134-138 oraz A. Stoff, Sześć "Spojrzeń" Stefana Grabińskiego, [w:] Od Kochanowskiego do Różewicza. Prace ofiarowane Arturowi Hutnikiewiczowi w siedemdziesiątą rocznicę urodzin, red. J. Kryszak, Warszawa 1988, s. 163-173.

${ }^{6}$ K. Irzykowski, Magik niesamowitości. Po zgonie Stefana Grabińskiego, [w:] idem, Lżejszy kaliber, Warszawa 1938, s. 83.

7 S. Grabiński, Wyznania „„Polonia” 1926, nr 141, s. 13.

8 Jak zrobiła to Krystyna Kłosińska w swoim odczytaniu Kochanki Szamoty, posługując się kategorią fantazmatu z psychoanalizy Freuda i Kristevej - zob. Fantazmaty. Grabiński - Prus - Zapolska, Katowice 2004. Na uwagę zasługuje także bardzo interesująca, choć może kontrowersyjna próba interpretacji noweli Czad przez Aleksandra Madydę, deszyfrującego ślady homoseksualnej męskości samego Grabińskiego poprzez lekturę tekstu literackiego - zob. "Czad" Stefana Grabińskiego, czyli kłopoty z płcia kulturowa, [w:] Polska literatura fantastyczna. Interpretacje, red. A. Stoff, D. Brzostek, Toruń 2005, s. 209-220. Wreszcie pomysł Barbary Zwolińskiej, która poprzez analityczne podejście do motywu wampira rozpatruje m.in. „ciemną erotykę" opowiadań Czarna Wólka, Engramy Szatery i W domu Sary - zob. Wampiryzm w literaturze romantycznej i postromantycznej, Gdańsk 2002.

9 S. Grabiński, Wyznania, s. 13. 
ści i zarazem uwieść swymi odkryciami czytelnika ${ }^{10}$, to właśnie czytelnik powinien wejść w dialektykę tego pożądania. Przyjemność czytelnika (może być zgodna, ale i sprzeczna z przyjemnością - także przyjemnością w cierpieniu - której doświadczał autor piszący tekst) to interpretacja. A sam czytelnik, idąc za Rolandem Barthes'em:

Obala wewnętrzne bariery, uwarunkowania klasowe, zakazy - nie przez synkretyzm, lecz zwyczajnie, pozbywając się starego upiora: sprzeczności logicznej; miesza wszystkie języki, nawet uznawane za niekompatybilne, znosi w milczeniu każde oskarżenie o nielogiczność, o niewierność. [...] Taki antybohater istnieje: jest nim czytelnik tekstu w chwili odczuwania przyjemności. Odwraca się wówczas stary mit biblijny, pomieszanie języków przestaje być karą, podmiot osiąga rozkosz, bo języki spółkują: tekst przyjemności, oto Babel szczęśliwa ${ }^{11}$.

Retoryka spod znaku Erosa obecna jest w rozważaniach Barthes’a o lekturze i pisaniu („Pisanie jest właśnie tym: nauką o rozkoszach języka, jego kamasutrąa” ${ }^{12}$. Retoryka ta wyziera również z wielu opowiadań Grabińskiego, którego różne odcienie erotyzmu pobudzały do rozważań o złożoności ludzkiej egzystencji ${ }^{13}$, jak i stanowiły momenty pochwytywania życia w jego najsilniejszych, ekstremalnych przejawach ${ }^{14}$. Wreszcie - sama retoryka Erosa, wspominana w tytule niniejszego artykułu, to nie tylko tropienie jej śladów w noweli Grabińskiego (choć to oczywiście zagadnienie kluczowe i pierwszoplanowe), ale także - na wyższym poziomie - to roz-mowa ${ }^{15}$ urzeczonego rozkoszą lektury czytelnika z tekstem, który w pewien sposób trzeba od tej lektury nieustannie oddalać. Niczym w opisanej przez Freuda dziecięcej zabawie Fort/Da!, moje postępowanie z materią tekstu będzie grą w oddalanie i przybliżanie sensów, by nie ulec pokusie jednoznacznego stwierdzania, które jest przecież pokusą tanatyczną. Tanatos całkowitego przybliżenia tekstu i nadania mu jednoznaczności jest z pewnością uwodzicielski, ponieważ zapewnia badaczowi iluzoryczne poczucie zrozumienia i właściwego odczytania utworu, a to dla interpretatora gwarancja sukcesu. W wypadku niektórych nowel Grabińskiego łatwo pokusić się o uzyskanie tej gwarancji, gdy sam autor podsuwa pewne spójne wyjaśnienia swoich niesamowitości ${ }^{16}$.

10 O tym, że Grabińskiemu niemalże obsesyjnie zależało na aprobacie czytających go, świadczy rozpacz, w jaką popadał, gdy tylko pojawiały się niepochlebne słowa krytyki pod jego adresem. Szerzej pisze o tym w swoich wspomnieniach o autorze J. E. Płomieński, Suweren polskiej fantastyki, [w:] idem, Twórcy bez masek. Wspomnienia literackie, Warszawa 1956.

${ }_{11}$ R. Barthes, Przyjemność tekstu, tłum. A. Lewańska, Warszawa 1997, s. 7-8 (podkr. - K. T.)

12 Ibidem, s. 11.

${ }^{13}$ Wspominał o tym J. E. Płomieński w recenzji tomu Namiętność, którego dominanty upatrywał właśnie w złożoności (krytyk rozróżniał u Grabińskiego portretowanie zarówno "fizjologii miłości", jak i "metafizyki płci”) niesamowitej erotyki - zob. Namiętność (recenzja), "Lwowskie Wiadomości Muzyczne i Literackie” 1921, nr 2, s. 3.

${ }^{14}$ Hutnikiewicz wskazywał, że: „Grabiński zmagający się w ciągu wszystkich lat swego krótkiego życia z widmem śmierci pragnął żyć, kochał życie. W takiej sytuacji stosunek do sfery doznań seksualnych z natury rzeczy musiał kształtować się bardzo swoiście. W popędzie płciowym wyrażał się dla niego niezniszczalny, triumfujący nad śmiercią witalny instynkt, rozkosz płciowa stawała się jedną z najbardziej intensywnych form utwierdzenia się w poczuciu własnego «jestem», «istnieję»" (TLSG, s. 243-244).

${ }_{15}$ Ten specyficzny zapis jest tu celowy, odnosi się bowiem do łacińskiego discursus, oznaczającego „rozproszenie”, „bieganie tu i tam”. „Roz-mowę” z tekstem Grabińskiego widzę właśnie jako inscenizowanie pewnej decentracji, gdzie podmiotowość piszącej interpretatorki pozostaje w nieustannej oscylacji wokół konstruowania sensów, a ruch przybliżenia się wcale nie gwarantuje ostatecznego spotkania, będąc raczej Barthes'owską rozkoszą oscylacji i nieprzerwanego bycia "pomiędzy".

${ }_{16}$ Tak można byłoby właśnie potraktować sytuację z Na wzgórzu róż - węchowa hipersensytywność bohatera naprowadza go na ślady okropnego morderstwa z nieodległej przeszłości. Nie deprecjonuję takiego

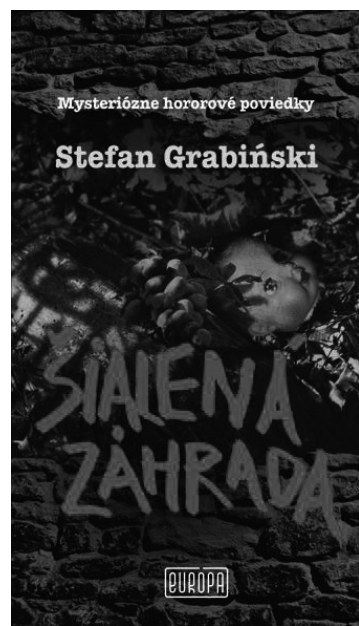

\section{S. Grabiński, Šialená záhrada. Mysteriózne hororové poviedky,} Vydavatel'stvo Európa, Bratislava 2010 
Ale chwila uległości jest zarazem momentem sprowadzającym śmierć na tekst. Nie jest to jednak erotyka w śmierci, a uczynienie z opowieści szpetnego truchła, które traci swą skłaniającą do ekstazy właściwość różnorodności. Dlatego erotyka Tanatosa, o której także wspominam w tytule, to strategia uwodzenia, rozumianego etymologicznie - jako odwodzenie (seducere - „zwodzić”, „odwodzić od właściwego kierunku”), uwodzenia otwierającego roz-mowę, której nawiązanie możliwe jest tylko w sytuacji „pomiędzy”. Tak bowiem, jak pożądanie męskiego bohatera $\mathrm{Na}$ wzgórzu róż trwa między fascynacją o podłożu erotycznym a tanatyczną odrazą, stopniowo przechylając się na stronę śmierci, która sama okazuje się fascynująca, tak i przyjęty przeze mnie tryb lektury rozkosznej powinien być raczej ruchem, aniżeli zastygnięciem. Choć przecież trudno przedwcześnie projektować kierunek uwiedzenia.

\section{Stońce}

Tytułowe opowiadanie ${ }^{17}$ tomu Na wzgórzu róż nie doczekało się jak dotąd osobnej (opublikowanej) interpretacji, tym bardziej pod kątem możliwej dialektyki erotyzmu i śmierci. Hutnikiewicz, poruszając to zagadnienie w swojej monografii, wskazuje jedynie na opowiadania noir, w których zauważa m.in. katalog zboczeń i perwersji „notowanych w rejestrach naukowej psychopatologii” (TLSG, s. 246). Istotnie, sporo erotycznych opowiadań autora $C z a d u$ operuje estetyką nocy, która osłania seksualne perwersje, zarazem wpisując je w przestrzeń śmierci. Tam gdzie splot erotyzmu i śmierci objawia się explicite, tam też zwykle musi wystąpić pod odsłoną nocy. W nowelach, takich jak Czarna Wólka, Engramy Szatery, Czad, w powieściach Salamandra i Cień Bafometa „nocy seksualnej odpowiada noc śmiertelna"18, a niszcząca siła popędu seksualnego jest metonimią rozkoszy w przerażeniu życiem, jako jedynej kondycji człowieka. Perwersyjny charakter erotyzmu, prowokowanego przez kobiece bohaterki (także te, których status ontologiczny jest niepewny - Jadwiga Kalegris z Kochanki Szamoty) niektórych opowiadań, wyraża się poprzez ciemność, rozmywającą twarde kontury rzeczy i rzeczywistości, otwierając pole dla mrocznej, destrukcyjnej rozkoszy.

W noweli Na wzgórzu róż sytuacja wygląda zupełnie inaczej. Bohater - narrator, działający z polecenia swojego lekarza, w ramach kuracji zdrowotnej ma zażywać kąpieli słonecznych. W tym celu znajduje w podmiejskich okolicach ustronną łąkę, która stanie się miejscem jego ekstatycznych doświadczeń. W opisie przestrzeni wzgórza wyeksponowana zostaje jej uboczność i pewna niedostępność wobec porządku życia miejskiego i obecności innych ludzi („Leżało za małym laskiem, odgrodzone od gościńca głębokimi jarami, zasłonięte przed okiem przechodnia łańcuchem pagórków”). Bajeczna łąka to przestrzeń całko-

odczytania, a jedynie pragnę wskazać na możliwość lektury innej, która - mam nadzieję - umożliwi dostrzeżenie pewnych subtelnie sygnalizowanych przez Grabińskiego zagadnień erotyzmu, śmierci i fantazji.

17 Wszystkie cytaty będą lokalizowane w tekście głównym za: W ustroni, „Lwowskie Wiadomości Muzyczne i Literackie" 1929, nr 5, s. 3. Jest to przedruk (pod zmienionym tytułem) z pierwszego wydania zbioru $\mathrm{Na}$ wzgórzu róż. Nowele, Kraków 1918.

18 Zob. P. Quignard, Noc seksualna, tłum. K. Rutkowski, Gdańsk 2008, s. 247. Opisuje on w sposób niezwykle ekspresyjny i zarazem liryczny nakładające się na siebie pola erotyzmu i śmierci, wskazując także, że seksualność to sui generis ekran, na który projektowane są fantazmaty o wzajemnej bliskości i przyległości partnerów. Do problemu tego powrócę jeszcze w dalszej części tekstu. 
witej samotności bohatera, separującej go od rzeczywistości zewnętrznej (choć i samo atopiczne wzgórze ulegnie przestrzennemu zróżnicowaniu, o czym jeszcze wspomnę), która przestaje mieć jakiekolwiek znaczenie, jej istnienie zostaje właściwie zawieszone wskutek uwodzicielskiego oddziaływania samotni, tonącej w „senliwej” ciszy i promieniach słońca:

Wybierałem umyślnie porę obiadową, gdy energia słońca dochodzi do szczytu. Wokoło mnie roztaczały całe bogactwa swych woni zioła prażone spiekotą południa, zanosily się brzękiem świerszcze. Wydzieliny rumianku i mięty, zawrotny zapach macierzanki unosily się w rozedrganym powietrzu gęstymi, ważkimi jak ciecz falami. Miałem wrażenie czegoś niemal dotykalnego... Zresztą cisza bezwzględna, senliwa. [...] Nade mną słońce czyste, bez skazy pławiło się $\mathrm{w}$ roztopionym złocie i wyginało łomkie brzegi tarczy połyskliwym ruchem...

Paradoks słońca polega na jego podwójnym oddziaływaniu. Energia słoneczna wyostrza właściwości rzeczy, intensyfikuje ich jakość i wymusza zwrócenie uwagi na zmysłowy spektakl woni, rozgrywający się wokół podmiotu. Bohater ma wrażenie niemalże zmaterializowanej obecności zapachów. Zarazem jednak gorące promienie, właśnie poprzez maksymalne podkreślenie cech przyrody, doprowadzają ją do pewnej hipertrofii obecności, odurzającej wystawiony na nią podmiot, który zdaje się roztapiać i zanikać, bo jej obecność, przekraczająca właściwą sobie kondycję, jest przecież niemożliwa do zobaczenia i dla konfrontowanego z nią podmiotu osuwa się $\mathrm{w}$ nieistnienie. Kontakt bohatera $\mathrm{z}$ realnością staje się więc coraz bardziej ograniczony, a autarkiczne percypowanie wrażeń wprowadza w stan błogiej senności. Senność jest też zasadą początkowych części tekstu. Ornamentacyjny ciąg zmysłowych signifiants, reprezentujących rozkosz bohatera, wydaje się odsuwać jakieś signifiée ${ }^{19}$, jakby autor chciał przedłużyć u czytelnika stan urzeczenia samą tylko powierzchnią słów, ich uwodzicielską materialnością. Być może tak jak dla bohatera tekstu, tak i dla czytelnika przewidziana została chwila słoneczno-tekstowego zatopienia się w ekstazie odrealnionej rzeczywistości, której chwilowo nie przytłacza żadne nadrzędne znaczenie ${ }^{20}$.

$\mathrm{Na}$ chwilę przed popadnięciem w ekstatyczne upojenie bohater patrzy prosto w słońce. Jego wzrok spotyka się z tym, co oczom zakazane, ponieważ - konstatuje Georges Bataille - „ludzkie oczy nie znoszą ani słońca, ani kopulacji, ani trupa, ani mroku, różnie jednak na nie reagują" ${ }^{21}$. Ze spojrzeniem skierowanym w słońce wiąże się fantazmat oślepienia lub chwilowego zawieszenia władzy wzroku ${ }^{22}$ (jak w wypadku bohatera noweli), dające możli-

19 Najwyraźniej zabieg ten będzie widoczny w przypadku woni róż - bardzo intensywnie wyczuwalnych, a zarazem niewidocznych, bo rosnących za murem odgradzającym pewną przestrzeń początkowo niedostępną dla bohatera - domagającej się nadania jakiegoś znaczenia, które bohater będzie projektował w wyobrażeniowych scenariuszach.

${ }^{20}$ W podobny sposób przestrzeń zagarniętą przez słońce konceptualizował Friedrich Nietzsche, który właśnie w rzeczywistości „pod czystym niebem” upatrywał możliwości doświadczania świata poza wszelką mediacją czy interpretacją. Słońce to „pragnienie sensu, epifanii, wyjścia poza oglądanie i mowę" - zob. M. P. Markowski, Nietzsche. Filozofia interpretacji, Kraków 1997, s. 405. Należy jednak nadmienić, że według autora Wiedzy radosnej słońce, jako synonim „niewinnej twórczości”, przeciwstawiać należało autonomicznemu poznaniu podmiotu, gdyż prowadziło do wyzwolenia z cienia własnej bierności. W pewien sposób wniosek ten dałoby się uzgodnić z kondycją podmiotu noweli - bohater tworzy, bo projektuje swoje wizje. Jednakże czyni to, pozostając biernym wobec rzeczywistości, jego aktywność fantazjotwórcza jest zarazem stopniowym oddalaniem się w autarkiczną sferę rzeczywistości wewnętrznej.

21 Zob. G. Bataille, Słoneczny odbyt, tłum. B. Banasiak, "Tygodnik Literacki” 1991, nr 11, s. 8. Fakt, że Bataille wymienia obok siebie zarówno słońce, jak i trupa, nie pozostanie dla moich rozważań bez znaczenia.

22 Zob. na ten temat uwagi Tomasza Swobody dotyczące mitów oślepienia, których bohaterowie w zamian za zmysł wzroku otrzymują zdolność wnikania w to, co niewidzialne - zob. idem, Historie oka. Bataille, 
wość dotarcia do realności innej aniżeli ta, która dostępna jest poprzez tradycyjne widzenie. „Ślepota jest mistyczna w tym sensie, że jest ekstazą, która przenosi podmiot przez «próg śmierci»" ${ }^{23}$. Dlatego ekstaza bohatera poprzedzona jest ruchem podniesienia głowy i obserwowania potężnego, południowego słońca, wraz z którym - choć nie będąc oślepionym w sensie dosłownym - wkracza w rzeczywistość swego pożądania, a jego egzystencja zmierza ku oddaniu się fascynacji. W południe, na niespełna kwadrans ekstasis bohatera staje się tożsama z existentia ${ }^{24}$.

\section{Rzeczywistość pożądania}

O swojej ekstazie bohater mówi, że nie identyfikował w niej żadnego obrazu (przynajmniej początkowo), a jedynie intensywną woń róż, które - według jego rozumowej dedukcji musiały kwitnąć w przestrzeni, od której odgradza go mur. Ten mur decyduje bowiem o szczególnej topografii samego wzgórza, odzielając świat wyobraźni bohatera od rzeczywistości ${ }^{25}$. Granica muru przepuszcza zapach kwiatów, zarazem nie pozwalając na unaocznienie jego rzeczywistego źródła. I o ile wcześniejsza woń ziół, możliwych do zobaczenia, uwodziła jedynie samym pozorem (nie domagała się rozszyfrowania czy symbolizowania), o tyle zapach róż zafiksowuje podmiot na konieczności przydania mu znaczenia i odnalezienia źródła. Zatem bariera wyznaczona murem może być doświadczana przez podmiot jako medium (ale i przeszkoda), które pobudza, wspomaga i napędza jego fantazję. Ciekawość co do niedostępnej przestrzeni stymuluje „wycieczki na niepewne, w krainę najdzikszych domysłów”. Bohater uparcie stara się dociec, czym mógłby być ów uwodzący go ślad. Pragnie wyprojektowania (a w konsekwencji uznania za prawdziwą) jakiejś obecności odpowiedzialnej za jego doświadczenie. Tyle że narracyjny fantazmat nie znajduje uzasadnienia w rzeczywistości, ponieważ: „Przykładałem ucho, uderzałem w mur kamieniami, parę nawet cisnąłem na drugą stronę - wszystko bez skutku: nie otrzymałem odpowiedzi. Dałem więc spokój, upewniony, że przestrzeń poza murem j e s t p u s t a i niezamieszkana przez ludzką istotę, co najwyżej zarosła różami [podkr. - K. T.]”. A zatem piękno odurzającego zapachu traci na atrakcyjności, jeśli nie kryje się za nim żadna obecność. Fantazmat, który nie ma swego rzeczywistego ugruntowania, przestaje być dla podmiotu interesujący, dlatego po trzech dniach snucia domysłów i odurzania się pustką kwestia zależności woni i tajemniczej przestrzeni za murem niemal przestaje go zajmować. Niemal, bo jednak pojawia się coś, co niepokoi i zdaje się pociągać dużo bardziej aniżeli cudowna woń róż. To inny zapach, który uchwyca (i przez który sam jest pochwyco-

Leiris, Artaud, Blanchot, Gdańsk 2010, s. 106-117. U Grabińskiego w Kochance Szamoty utrata klarowności postrzegania wiąże się ze spojrzeniem na grecką tarczę z wizerunkiem Meduzy, które to spojrzenie bohatera zawsze poprzedza nadejście widmowej kochanki - zob. K. Kłosińska, op. cit., s. 24. Idąc tym tropem, można się zastanawiać, czy dopiero zahipnotyzowane oko w stanie zawieszonych możliwości racjonalizowania otwiera bohatera na nadejście Jadwigi, będącej przecież tworem z porządku realności fantazmatycznej.

${ }_{23}$ A. Hussey, The Inner Scar: The Mysticism of Georges Bataille, Amsterdam 2000, s. 90.

${ }^{24}$ Quignard twierdzi, że ekstasis jest wyjściem poza siebie (poza ciało i czas) i zarazem greckim odpowiednikiem łacińskiego existentia (P. Quignard, Życie sekretne, tłum. K. Rutkowski, Poznań 2006, s. 96). To utożsamienie w wypadku bohatera Na wzgórzu róż będzie się pogłębiać w dalszej części opowiadania.

${ }_{25} \mathrm{Na}$ tym etapie opowiadania precyzyjne rozróżnienie ontologii obu porządków wydaje się możliwe. Jednakże w dalszej jego części teza ta podlegać będzie problematyzacji. 
ny) podmiot, staje się elementem napędzającym jego działania. Jaki to zapach? Jak twierdzi sam bohater:

Zapewniam, że aż do rozwiązania zagadki nie miałem pojęcia o jego istocie, tak, żebym przy pomocy normalnych, codziennych, że się tak wyrażę, funkcji powonienia nie mógł nic wnioskować o źródle jego pochodzenia. Domyślałem się tylko, że ów szczególny zapach, który wnęcił się pomiędzy dotychczasowe, izolowany, zapewne musiałby być znacznie silniejszy i wyraźniejszy, lecz w obecnej sytuacji byl przytlumiony i przekształcony przez inne.

Zapach śmierci, bo o nim mowa, radykalnie nie przystaje do sytuacji rozkosznej ekstazy, którą zapewniały dotychczasowe wonie. Tyle że on sam nie potrafi jeszcze nazwać tego, co wyczuwa. Tak jakby śmierć była zupełnie niemożliwa do wintegrowania w jego obecną sytuację, a jej zidentyfikowanie możliwe jest dopiero ex post, gdy już zaistnieje. Mortualny odór ma jednak moc fascynowania do tego stopnia, że w kolejnej ekstazie do powonienia dochodzi także projekcja kobiety, w której zakochuje się bohater.

Skoro podmiot nie jest świadomy, że parametry jego pożądania ustawia śmierćć ${ }^{26}$, to można by zaryzykować tezę, że niemożliwa do nazwania/symbolizowana w tekście woń śmierci jest śladem ${ }^{27}$ Lacanowskej das Ding (Rzeczy), która w zakończeniu noweli „powraca na swoje miejsce i jest najbardziej fundamentalną z ludzkich pasji”, jak pisze Sean Homer $^{28}$. To - konstatuje dalej autor - „przedmiot-przyczyna pożądania, ale może być konstytuowany tylko retroaktywnie"29. Rzecz to właściwie nie-rzecz (no-thing), bo istnieje tylko jako „coś” w momencie, gdy znajdzie się podmiot pożądający jej. Zapach, o jakim pisze Grabiński, zapewne nie fascynowałby, gdyby nie zainteresowanie bohatera, który zarazem dzięki tej niezidentyfikowanej woni może snuć dalsze fantazje, bogatsze teraz także o obraz.

\section{Kobieta}

W kolejne słoneczne popołudnie „opity słońcem” bohater odchyla głowę i spogląda tam, gdzie mur styka się z niebem, dostrzegając tuż ponad murem kształt głowy. Ta projekcja

${ }^{26}$ Czytelnik podążający za tekstem linearnie znajduje się w tej samej sytuacji co bohater. Jego zainteresowanie tekstem/zapachem również ufundowane jest na nieświadomym pragnieniu śmierci zarówno w sensie, o którym pisałam we wstępie - jako wyjaśnienie i zrozumienie sensu tekstu holistycznie, jak i - na poziomie tego konkretnego fragmentu - na śmierci, która generuje chęć dalszej lektury, gdyż - co okazuje się na końcu tekstu - to śmierć właśnie odpowiada za sterowanie fascynacją, która motywuje lekturę. Tak jak w wypadku bohatera, który nieświadomie dąży do konfrontacji z tanatycznym rewersem swojego pragnienia. Oczywiście, można zaprzeczyć i stwierdzić, że czytelnik dostał przecież od Grabińskiego aforyzm, dwuwiersz z neapolitańskiej piosenki, który występuje w charakterze motta (W ustach co niegdyś tchnęły woniq kwiatu,/Robak się lęgnie - bolesny widoku!). Aforyzm jest jednak (zahaczając nieznacznie o ustalenia Derridy z Niewczesnych aforyzmów, tłum. M. P. Markowski, „Literatura na Świecie” 1998, nr 11/12) niewczesny, tj. aktualizuje się dopiero w momencie zakończenia lektury, a w chwili jej rozpoczęcia nie jest zrozumiały.

${ }^{27}$ Gdyż Rzecz nie podlega symbolizacji. Ślad jest czymś, co odciska ona w podmiotowości i co staje się motorem działań, by ów odcisk zidentyfikować. Dla bohatera noweli konfrontacja z samą Rzeczą doprowadzi do rozpoznania swojego pożądania jako zachwycenia śmiercią.

${ }_{28}$ S. Homer, Jacques Lacan, Routledge Critical Thinkers, London-New York 2005, s. 82.

29 Ibidem, s. 85.

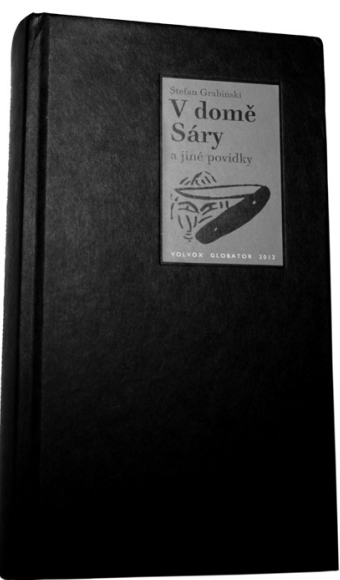

\section{S. Grabiński, V domě Sáry} ajiné povidky, Volvox

Globator, Praha 2012 
wzbudza rzeczywisty lęk, który staje się namiętnością bohatera i podsyca jego pragnienie kolejnego doświadczenia solarnej ekstazy ${ }^{30}$.

Gdy rozgrzanie ziemi i roślin osiągnęło swój punkt zwrotny, znów uczułem wśród chaosu woni tę jedną, nieuchwytną, chociaż teraz już nieco dobitniej zaakcentowaną.

W przekonaniu, że zjawie istotnie brak wszelkiego rzeczywistego źródła, wytężałem wzrok i siliłem się, by zachować przytomność umysłu, chcąc w ten sposób zapobiec jej wyłonieniu się. Tymczasem słońce, róże, a może i o w o coś, n i e z n a n e w z i ę $ł$ o g ó r ę, ob e z $\mathrm{w} \nmid$ a $\mathrm{d} \mathrm{n}$ i ło $\mathrm{m} \mathrm{n}$ i e i w samo południe ujrzałem pochyloną nade mną przez zrąb muru subtelnie piękną, tym razem wyraźnie kobiecą głowę.

Czy owym „czymś” nie może być właśnie to niezsymbolizowane coś, czego pożąda bohater i co zarazem strukturyzuje jego pożądanie, tym samym poprzedzając je? To „coś”, co bohater w jakiś sposób postrzega jako obce mu, a nawet wrogie, gdyż stara się przed „tym” bronić poprzez zachowanie pełni władz umysłowych, a jednak poddaje się „temu”, przyznając „mu” przewagę nad swoim ratio. Projekcję pięknej kobiecości („owal twarzy był pociągly, szlachetny, źrenice w perłowej oprawie białek i włosy ujęte w tyle głowy w grecki węzeł") można by potraktować jako zasłonę, jaką czyni podmiot z fantazji, by zamaskować niepokojącą go Rzecz. Kobieta byłaby zatem elementem pożądania podmiotu, rzutowanym na ekran fantazji, która „aby mogła funkcjonować, musi pozostawać «niewyrażona», musi zachowywać dystans wobec wyraźnie sformułowanej tkaniny symbolicznej, którą podtrzymuje”31. „Tkanina symboliczna” - czyli porządek rzeczywistości - jest jeszcze wyraźnie przez bohatera wyodrębniany, bo przecież sam zauważa: „koloru ich [włosów kobiety] oznaczyć nie mogłem, bo substancja, z której zjawisko utworzyło swą postać, była nieokreślonej, galaretowatej barwy”. „Substancja”, „zjawisko”, „galaretowata barwa” - to sztafaż określeń godny spirytualisty czy specjalisty od mediumizmu ${ }^{32}$, nie zaś mężczyzny, który właśnie poddaje się uwodzącej go kobiecie. Czy ta paranaukowa terminologia nie jest dowodem na rozpaczliwą próbę ocalenia swojej pewności co do statusu porządku rzeczywistego i fantazmatycznego i ich koniecznej rozdzielności? Podmiot sam mówi przecież o idealnym pięknie kobiety, biorąc je za projekcję swojej wyobraźni („Była tak niezwykle piękna, że wziąłem ją za uosobiony ideał mej wyobraźni wyrzucony na zewnątrz szczególnym sposobem w stanie zachwytu"). Mimo to (a może właśnie dlatego) kieruje ku niemu swoje miłosne pragnienie, zakochuje się w cudowności swego doświadczenia. Eros, który rodzi się w tym doświadczeniu, ma jednak (w mojej interpretacji) funkcję maskującą wobec prymarnego odczucia niepokojącej i niezidentyfikowanej przez podmiot woni śmierci, która stała się odpowiedzialna za jego zainteresowanie tym, co może skrywać przestrzeń poza murem. Jednakże on sam, by ustanowić dla siebie swoje pożądanie, potrzebuje „niezbędnego mi-

${ }^{30}$ W tej noweli ekstatyczny stan osiągnąć można tylko poprzez słońce. Kiedy jednego dnia niebo jest zachmurzone, zrozpaczony tym faktem bohater nie może doświadczać swoich fantazji i niecierpliwie oczekuje powrotu tak potrzebnych mu promieni słonecznych.

${ }^{31}$ Zob. S. Žižek, Przekleństwo fantazji, tłum. A. Chmielewski, Wrocław 2009, s. 32.

32 Co akurat nie dziwi, Grabiński bowiem wprowadził do wielu swoich utworów zagadnienia parapsychologii i mediumizmu, nierzadko czyniąc ze swoich bohaterów specjalistów w dziedzinie zjawisk metapsychicznych. Problematykę szeroko komentuje Hutnikiewicz, zwłaszcza w rozdziale III monografii. Moja interpretacja idzie jednak w stroną inną niż spirytualistyczna. 
nimum idealizacji rzeczywistości”33, poprzez wyprojektowanie uwodzicielskiego obrazu. Jak się bowiem okaże - rzeczywistość pozbawiona swojej fantazmatycznej przesłony jest nie do zniesienia, ale właśnie poprzez odsłonięcie elementu bólu to przestrzeń Realnego rzeczywistości (w sensie Lacanowskim) okaże się najbardziej rozkoszna. Tak dla bohatera, jak i dla czytelnika.

Fantazmatyczna kobieta „patrzyła smutno, z wyrzutem” (podkr. - K. T.). I dalej: „Gdy chciałem przemówić, rozwiała się". To spojrzenie z niemym wyrzutem wspominane przez podmiot potrzebne jest mu do zbudowania wizji kobiety jako tej, która skrywa pewną tajemnicę. Tajemnica jej smutku jest tym, co popycha go do kolejnych ekstatycznych wizji. To od nich będzie się spodziewał rozwiązania. Byłoby więc może tak, jak chce Žižek, który zaznacza:

Nigdy nie należy zapominać, że pożądanie „zrealizowane” (odegrane) w fantazji nie jest własnym pożądaniem podmiotu, lecz jest pożądaniem cudzym: fantazja, fantazmatyczne ksztaltowanie, jest odpowiedzią na tajemnicę „Che vuoi?”: „Mówisz tak, ale czego wtaściwie chcesz, gdy to mówisz?", która wyraża pierwotną konstytutywną pozycję podmiotu. Pierwotne pytanie o pożądanie nie jest bezpośrednim pytaniem „Czego ja chcę?”, lecz „Czego inni chcą ode mnie? Co oni we mnie widzą. Czym jestem dla innych?"34.

Aby ukonstytuowało się pożądanie bohatera ukrywające potworność zapachu, potrzebna jest projekcja kobiety, która zaaferuje podmiot na tyle, by mógł on oddać się fantazjowaniu. Skoro jednak mężczyzna sam mówi, że kobieta jest tylko eksterioryzacją jego ideału, a zatem nie jest wobec niego zewnętrznym, autonomicznym bytem, to także samo uwiedzenie, jakiego doświadcza bohater, jest autouwiedzeniem par excellence. Dzieje się tak, gdyż - jak podaje za Vincentem Descombesem Jean Baudrillard - „osoba uwodzona odnajduje w innym to, co ją uwodzi, niepowtarzalny przedmiot swojej fascynacji”" ${ }^{35}$. W noweli Grabińskiego uwiedziony dosłownie „wymusza” na uwodzicielce ujawnienie przedmiotu swojej fascynacji - tajemnicy, wobec której będzie się czuł zobligowany do podtrzymywania fantazmatycznej rzeczywistości swojej egzystencji. Ten niemy wyrzut kobiety, w którym bohater być może odczytuje pytanie Che vuoi?, wymaga od niego reakcji, wzbudza fascynację prowadzącą go w stan zauroczenia wyobrażeniową pięknością. Dlaczego jednak piękność nie posiada głosu? Nie werbalizuje swoich oczekiwań, co więcej, rozwiewa się, ilekroć tylko podmiot usiłuje nawiązać z nią komunikację dyskursywną? Wróćmy jeszcze do Baudrillarda, niezrównanego, gdy chodzi o uwodzenie:

Wszystko, co da się wyjawić, nie należy do tajemnicy. Nie jest ona bowiem ukrytym znaczeniem, ani jakimkolwiek kluczem do czegokolwiek, lecz czymś, co krąży w tym, co wypowiadane i zewsząd je przenika - tak jak uwodzenie przepływa pod obscenicznością mówienia - jest odwrotnością komunikowania, choć zarazem czymś, co się udziela. Tajemnica zawdzięcza swą moc tylko temu, że nie jest wypowiadana, podobnie dzięki kategorycznej niewypowiadalności funkcjonuje uwodzenie.

${ }^{33}$ Zob. S. Žižek, op. cit., s. 22. Funkcją fantazji jest jednak nie tylko kamuflowanie horroru Realności, bo stosunek między tymi sferami jest bardziej wieloznaczny. Otóż fantazja maskuje, ale i kreuje to, co pragnie ukryć, wytwarza swój „wyparty” punkt odniesienia. Ta wieloznaczność fantazji będzie mogła tłumaczyć moje rozumienie mortualnego pożądania podmiotu jako wykreowanego z niego samego.

34 Ibidem, s. 26.

35 J. Baudrillard, O uwodzeniu, tłum. J. Margański, Warszawa 2005, s. 68. 
[...] Pozostaje [tajemnica] formą wtajemniczającą, implozyjną: wchodzi się w nią, lecz nie sposób z niej wyjść: nie ma mowy o jej wyjawieniu, zakomunikowaniu czy „dopuszczeniu” do niej: stąd właśnie czerpie swoją siłę, na tym polega jej zdolność opartej na aluzji i rytuale wymiany $^{36}$.

Fantazja ustanawiająca pozadyskursywną tajemnicę ustanawia również pragnienie bohatera. Chodzi w niej więc nie tyle o sam obiekt, co o wyznaczenie szczególnych parametrów, które nadadzą ramę miłosnej fascynacji ${ }^{37}$. Celowo piszę tu o „nadawaniu ramy”, co sugeruje pewną zamkniętą, statyczną kompozycję, w której obwarowuje się zafascynowany podmiot. Wydaje mi się bowiem, że na tym etapie rozkoszogenna tajemnica zaprojektowana przez bohatera wtrąca go w pewien stan biernego urzeczenia. Jak sam deklaruje: „Rozkochałem się w nim [ideale kobiecości] do niepamięci i żyłem tylko krótkimi, nazbyt dla mnie krótkimi chwilami, w których mi się ukazywała”. Pisałam już wcześniej o pewnej szczególnej kondycji podmiotu Na wzgórzu róż, czyli o egzystencji jako ekstazie. Od momentu „pojawienia się" kobiety zdaje się on żyć t y lk o poprzez doświadczanie rozkoszy, jaką zapewniają mu ekstatyczne wizje, zamazujące (zgodnie z pomyślaną dla nich rolą) ślad niepokojącego zapachu w cudownej woni róż. Jednak z tego stanu biernej, ekstatycznej egzystencji wytrąci go coś, wobec czego nie będzie mógł pozostać obojętny.

\section{Skaza tekstu/tekst jako skaza}

Aż razu jednego - był to już czwarty dzień z rzędu, od czasu pierwszego wyłonienia się - spostrzegłem z przerażeniem zagadkową zmianę w tej anielskiej twarzy. Jakaś ciemna jak otchłań plama wykwitła na prawym licu. Nazajutrz rozszerzyła się gwałtownie i objęła czoło. Była podobna do plam, które w jasną noc widać na tarczy księżyca: wiała z nich pustka i chłód. Niebawem wzdłuż jej rąk przeciągnęły się również niepokojące cienie.

Ta niepokojąca zmiana na ciele pięknej kochanki zaszczepia w podmiocie pragnienie przekroczenia muru i skonfrontowania swojej fantazji z rzeczywistością. Mur - funkcjonujący wcześniej jako stymulujące fantazję medium - teraz okazuje się przeszkodą ${ }^{38}$, którą należy pokonać, by dokonało się odsłonięcie sensu frapującego defektu. Innymi słowy - dopiero ta niezrozumiała skaza staje się przyczyną zagadki. Zagadki tak kuszącej, że niemożliwe staje się dłuższe ograniczanie do sfery wyobrażeń, gdyż rysa, w mniemaniu podmiotu, jest

\footnotetext{
${ }^{36}$ Ibidem, s. 78.
}

37 Taka jest zresztą rola każdej fantazji, której zadaniem nie jest nawet samo dostarczanie podmiotowi gotowego obiektu, ile raczej „strukturyzowanie ustawień" pożądania. Zob. J. Laplanche, J.-B. Pontalis, Fantasy and the Origin of Sexuality, [w:] Formations of Fantasy, ed. V. Burgin, J. Donald, C. Kaplan, London 1986, s. 26.

${ }^{38}$ O podobnej zależności muru, fantazji i rzeczywistości pisze Paweł Dybel w swojej psychoanalitycznej interpretacji Dziewczyny Bolesława Leśmiana. Zob. idem, Urwane ścieżki: Przybyszewski - Freud - Lacan, Kraków 2000 , s. 246-248. Autor zauważa, że w wierszu Leśmiana bracia, motywowani pragnieniem dotarcia do źródła głosu, rozbijają mur, odsłaniając wówczas nie upragnioną obecność dziewczyny, lecz katastrofę - nicość, która okazuje się nieunikniona, gdy zniesieniu ulegnie granica dzieląca podmiot od obiektu jego pragnienia. Finał noweli Grabińskiego również okazuje się katastrofalny wskutek przekroczenia dystansu. Tyle że katastrofa ta przynosi podmiotowi noweli nieco inne rozpoznanie swojej sytuacji. 


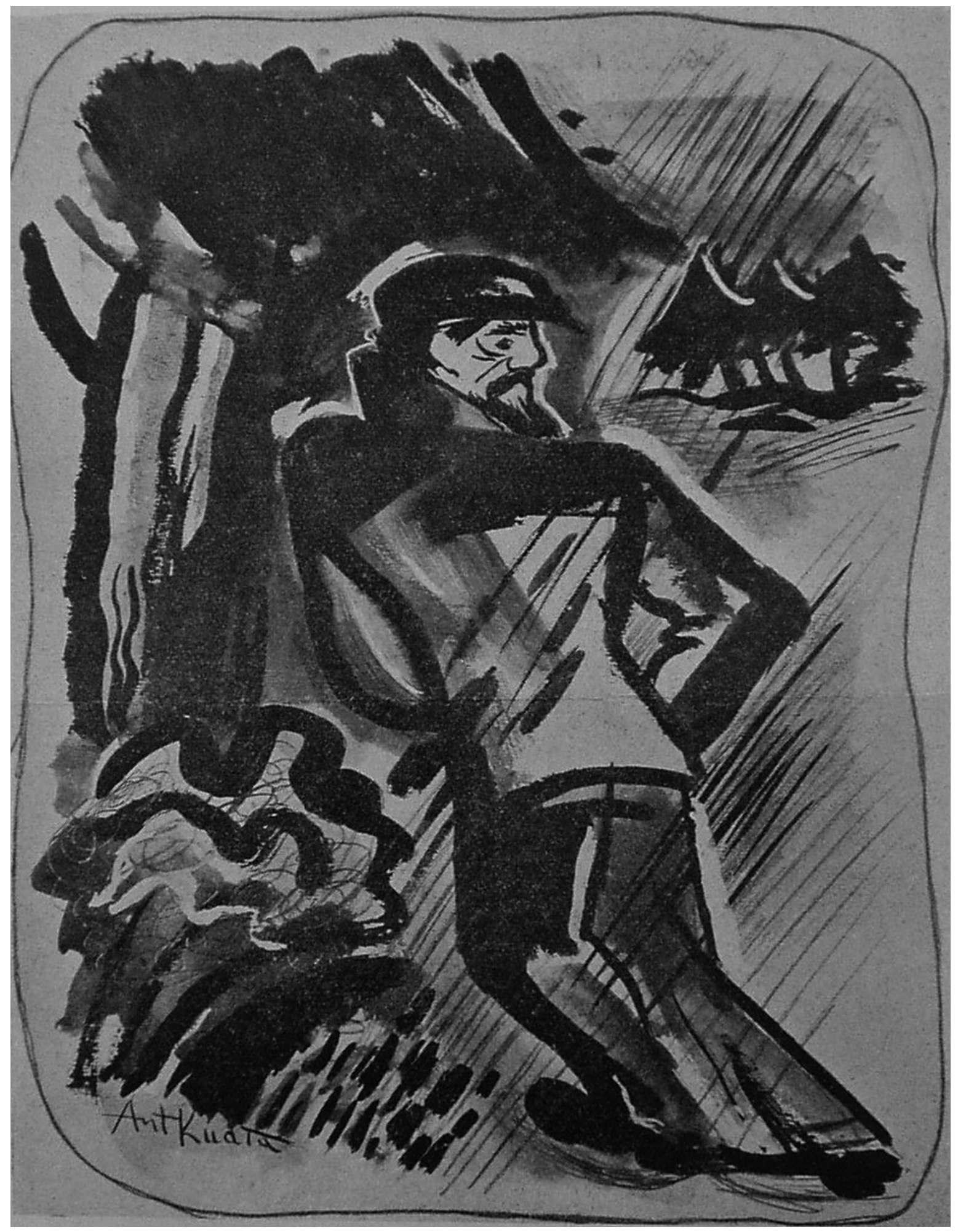

Ilustracja do noweli Lepianka w czystym polu ,,Pion"1933, nr 13 (30 XII), rys. Antoni Kudła 
bardziej rzeczywista niż jej idealne piękno, które sam przecież uznał za wytwór swojego umysłu.

W paradygmatycznej dla myślenia o ranie (skazie, cięciu, rysie) scenie opowiadania Kafki Wiejski lekarz ${ }^{39}$ pojawia się opis otwartej, krwawiącej rany, która ma wielkość dłoni i jest pokryta grubymi jak palec robakami. Komentując tę scenę, Michał Paweł Markowski zastanawia się, czym może być ta rana. Proponuje uznać, że jest ona: „Tym ciemnym miejscem, die wolkige Stelle, opowiadania, w którym życie, chcąc nie chcąc, wychodzi na jaw. Rana jest epifanią nieludzkiego w człowieku. Rana jest dziurą zarówno w egzystencji, jak

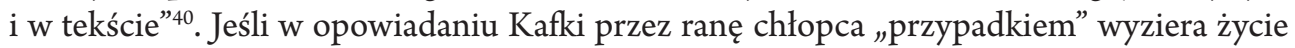
w jego najbardziej przerażającej, somatycznej formie, to można by analogicznie zapytać, co wychodzi na powierzchnię ciała kobiety w opowiadaniu Grabińskiego? Interpretując ten fragment ex post, po przeczytaniu całości tekstu, czytelnik wie, że tym czymś jest śmierć, a podmiot zaczyna po prostu obserwować postępujący rozkład ciała ukochanej. Jednakże $\mathrm{w}$ chwili, gdy nie rozpoznaje on oszpecającego twarz kobiety ornamentu, znamię wydaje się czymś bardziej rzeczywistym niż ona sama jako nieskazitelna piękność. To nierozpoznanie ma także kluczowe znaczenie dla samego tekstu opowiadania. Od tego momentu bowiem zawiązuje się całe dochodzenie, które na wzór kryminalnej zagadki podejmuje bohater. Ta zwizualizowana tym razem epifania Rzeczy (przerażającej podszewki rzeczywistości) jest więc w pewnym sensie także źródłem opowieści, choć w sposób bardzo znaczący wytrąca czytelnika z dotychczasowego stanu zadowolenia, które udzielało się wskutek spełnionej pracy fantazji bohatera, maskującej nieuzasadnioną woń. Można by nawet powiedzieć, że mortualne znamię odciskając się na tekście, zarazem wyciska go, konstytuuje i retroaktywnie czyni z siebie początek historii. Jacques Derrida pisze o powstającej w ten sposób opowieści, że: „Sygnatura to rana i nie istnieje żadne inne źródło sztuki. Nie ma innego źródła piękna, tylko ta rana - pojedyncza, dla każdego różna, ukryta lub widoczna - którą każdy w sobie podtrzymuje, konserwuje i w którą wycofuje się, gdy chce uciec od świata i popaść w chwilową, lecz absolutnie głęboką samotność" ${ }^{41}$.

Narrator Na wzgórzu róż pogrąża się w otchłannej plamie na twarzy ukochanej, ale po to, by wyjść poza rzeczywistość fantazmatu i wkroczyć w rzeczywistość Realności swego pożądania, które motywowane jest osobliwym pociągiem ku rozwiązaniu tajemnicy. Rozkosz, jaką czerpie z możliwości aktywnego działania, staje się także udziałem czytającego tekst i konfrontującego się ze stopniowo wypełnianą plamą twarzy i tekstu. To rozkosz, której przestał wystarczać uspokajający fantazmat pięknej, niemej uwodzicielki, zaszczepiający się na odpychającej plamie, otchłani, niedającej połączyć się z przyjemnym doświadczeniem estetycznym. To w końcu rozkosz urzeczenia tym, co w pewien sposób przerażające. O takiej właśnie fascynacji pisał Bataille, gdy zaznaczał, że „we wszelkim przerażeniu kryje się możliwość urzeczenia [...], że w przerażeniu skrywa się zawsze możliwość pożądania”42. Ta intruzja przerażającego skutkuje więc przekroczeniem fantazji (Lacanowskie la traversée du phantasme) i wzięciem odpowiedzialności za swoją rozkosz, tj. dążeniem do konfrontacji z jej praprzyczyną, tkwiącą w twardym jądrze rzeczywistości. Cóż to jednak za rozkosz, która płynie z doświadczenia odpychającego, ze zniekształcenia piękna? Myślę, że można

\footnotetext{
${ }^{39}$ F. Kafka, Proces. Wyrok, tłum. B. Schulz, J. Kydryński, Warszawa 1981, s. 219-20.

40 M. P. Markowski, Życie na miarę literatury, Kraków 2009, s. 324.

41 J. Derrida, Glas, trans. J. P. Leavey, R. Rand, Lincoln 1986, s. 184.

42 G. Bataille, Historia erotyzmu, tłum. I. Kania, Warszawa 2008, s. 126, 129.
} 
byłoby tu wskazać na Lacanowską jouissance jako na rozkosz w przerażaniu, a nawet bólu. To właśnie jouissance „stanowi esencję i prymarną jakość, która nadaje życiu człowieka wartość i znaczenie" ${ }^{\prime 3}$. W wypadku podmiotu noweli Grabińskiego nadaje mu także konkretny cel. Warto zauważyć, że mężczyzna, rezygnując z dalszego fantazjowania i decydując się na przerzucenie poza mur drabiny, wierzy, że za nim jest coś więcej niż to, czego do tej pory doświadczy $1^{44}$. Coś, co zaspokoi jego ciekawość bardziej, niż wpisana w zasadę przyjemności fantazja o ideale. By dostać się do jouissance, trzeba wykroczyć poza zasadę przyjemności. A wykroczenie to dokonuje się po to, by w ostatecznym spotkaniu odkryć, że kierowani jesteśmy nie tyle w stronę śmierci (jak chciał tego Freud), co p r z e z s a m ą ś m i e rć, budzącą erotyczną fascynację (jak uzupełnia Lacan).

\section{Przekroczenie fantazji}

Bohater trafia za mur, gdzie wkracza do wytwornej willi otoczonej bajecznym ogrodem: „klomby kwiatów, aleje, kobierce trawników, inspekty, cieplarnia, wypełniały resztę w całość marzennie piękną". $Z$ detaliczną precyzją odtwarza oglądaną rzeczywistość przepychu przestrzeni tak, że tworzy się w tekście ornamentacyjny ciąg przedmiotów, ich barw, faktur i kształtów, które zatrzymują obraz w nieruchomym trwaniu baśniowej atmosfery. Zgodnie z tym, co deklaruje sam narrator, ogląda miejsce rzeczywiste, a jednak sposób, w jaki je percypuje, daje wrażenie jakiejś fantazmatycznej enklawy, wykluczonej spod działania czasu. Enumeracyjne ciągi wyliczeń zdają się zaburzać granice rzeczywistości ku jakiejś fantasmagorycznej iluzji. Mocny status ontologiczny przestrzeni pod wpływem cudowności kreującego ją języka zdaje się tracić swe wyraźnie zarysowane kontury i wraz z odurzonym bohaterem rozpraszać się i zatracać substancjalność. Wszystko dzieje się w spowolniającym tempie, by w konsekwencji wtrącić bohatera w senność. Nim to jednak nastąpi, znajdzie on flakon z trucizną. Tyle że fakt ten zostanie zawieszony. Zrodzi się pewne napięcie, ale na jego rozładowanie przyjdzie jeszcze poczekać. Jakby spotkanie z głębią pożądania wymagało nieustannego przesunięcia, a nawet niejako mylenia podmiotu i czytelnika. Na tym etapie bowiem bohater podtrzymuje pewną łagodzącą i retardacyjną strategię oswajania rzeczywistości. W sennej wizji pojawia się jego ukochana, spierająca się z inną postacią („mężczyzną niezawodnie”, powie później narrator), która szarpie kobietę. Tu jednak jeszcze nie kończy się senna projekcja. Znów następuje chwilowe zawieszenie, odwlekające spotkanie z porażającą Realnością. Kobieta bowiem podnosi się, a z jej dłoni wysuwa się chusteczka, którą jeszcze przed zaśnięciem znalazł bohater. Dopiero, gdy chusteczka upada na posadzkę, pożądana przez śniącego kobieta odchodzi ... w kierunku róż. A narrator budzi się do rzeczywistości. Ale dlaczego? Co właściwie budzi go w chwili, gdy materia snu mogła mu podsunąć upragnione rozwiązanie tajemnicy? Być może pomocna okaże się tu pewna opowieść, którą w Objaśnianiu marzeń sennych przytacza Freud:

${ }^{43}$ E. Ragland, Essays on the Pleasure of Death: From Freud to Lacan, London 1995, s. 88.

44 Jak odnotowuje Bruce Fink: „W dążeniu do konfrontacji z jouissance myślimy, że gdzieś musi być coś lepszego; mówimy, że jest coś jeszcze lepszego; wierzymy, że istnieje coś lepszego". To coś, co egzystuje (ex-iste) poza nami i domaga się aktu przekroczenia. Zob. idem, Knowledge and Jouissance, [w:] Reading Seminar XX: Lacan's Major Work on Love, Knowledge and Feminine Sexuality, ed. S. Barnard, B. Fink, New York 2002, s. 35. 
Ojciec czuwa dniami i nocami u łóżka złożonego chorobą dziecka. Kiedy dziecko umiera, ojciec udaje się do pokoju obok, by wypocząć, zostawia jednak drzwi otwarte, tak że z sypialni może widzieć pokój, gdzie złożono zwłoki otoczone gromnicami. Przy ciele czuwa starzec - siedzi przy katafalku, mrucząc modlitwy. Po kilkugodzinnym spoczynku ojcu śni się, że dziecko stoi u jego łóżka, bierze go w ramiona i szepcze z wyrzutem: „Ojcze, czyż nie widzisz, że płonę?” Ojciec budzi się, patrzy, a tu z pokoju, gdzie złożono zwłoki, bije wielka jasność; zrywa się z łóżka, biegnie i co widzi? Siwowłosy starzec drzemie, a ubranie i jedna ręka drogich szczątków płoną, zajęte od płomienia świecy, która upadła na katafalk ${ }^{45}$.

Przytaczam tę Freudowską historię w całości, ponieważ wydaje mi się ona pomocna do uzyskania odpowiedzi na postawione wcześniej pytanie. Przypomnę, że bohater $\mathrm{Na}$ wzgórzu róż budzi się oślepiony blaskiem - refleksem bijącym od szklanych ścian pomarańczarni, które przeszywając okno pokoju, dosięgają go w półmroku. Refleks ten zbiega się z ostatnim elementem wizji sennej - błyskiem lśniącej, szafirowej strzały, utkwionej we włosach kobiety patrzącej przez okno. Jej oczy świecą suchym, szklanym blaskiem. Dostrzegam tu (za Freudem) pewne continuum snu i jawy. Czy byłoby zatem tak, że na bohatera działa pewien bodziec zewnętrzny (odbity blask), który budzi go, niczym ojca wybudza płomień świecy? Zapewne można byłoby przyjąć i taką interpretację, ale mam wrażenie, że uprawniona jest także i inna wersja, która mnie samej okaże się bardziej pomocna. Czy to spojrzenie ukochanej z fantazji nie dotyka głębszej, Realnej rzeczywistości, wobec której podmiot czuje się bezradny? W wizji nie może on przecież zapobiec nadchodzącej katastrofie, nie potrafi zaradzić pustemu spojrzeniu kobiety, spojrzeniu podobnemu skardze syna kierowanej do ojca we Freudowskiej narracji. Lacan, reinterpretujący tę właśnie opowieść, zwraca uwagę, że ojciec budzi się, bo doświadcza zbyt uporczywie pewnej „innej, brakującej rzeczywistości swego pragnienia" ${ }^{6}$ i właściwie w chwili przebudzenia kontynuuje swój sen, by nie stawiać czoła temu, czego niepodobna uchwycić in effigie, czyli właśnie Realności swego pożądania. Lacanowskie rozważania kontunuuje Žižek, którego zdaniem: „budząc się do codziennej rzeczywistości zwykle z ulgą stwierdzamy «To był tylko sen», tym samym jednak przeoczając najbardziej znaczący fakt, że «być na jawie, to nic innego, jak tylko pozostawać świadomością swego snu»" snu, powraca do kojącej rzeczywistości, by zatrzeć ślad swojego przerażającego spotkania z Realnością. Przebudzenie bohatera $\mathrm{Na}$ wzgórzu róż powodowane jest właśnie dotarciem, możliwie najbliżej, do rozwiązania zagadki o strukturze jego pożądania. Można byłoby się zastanawiać, czy gdyby spał on nieco dłużej, nie ujrzałby agonii otrutej przez innego mężczyznę kobiety? Albo gdyby Grabiński nie umieścił informacji o przebudzeniu bohatera, czy nie mielibyśmy zwyczajnie do czynienia z działaniem właściwym somnambulikowi? A przecież bohater wyraźnie zaznacza „obudziłem się”, po czym kontynuuje docieranie do prawdy snu, czyli do odsłonięcia śmierci będącej w istocie imieniem jego pożądania.

\footnotetext{
45 S. Freud, Objaśnianie marzeń sennych, tłum. R. Reszke, Warszawa 1996, s. 429.

${ }^{46}$ J. Lacan, Touché i automaton, tłum. K. Kłosiński, [w:] Teorie literatury XX wieku. Antologia, red. A. Burzyńska, M. P. Markowski, Kraków 2006, s. 32.

47 S. Žižek, Looking Awry: An Introduction to Jacques Lacan through Popular Culture, Cambridge 2000, s. 13.
} 


\section{Rozpoznanie}

Kobieta (jeszcze we śnie podmiotu) znika wśród róż. Tych odurzających na początku noweli pięknem swojej woni, wokół której bohater rozbudowywał fantazmatyczne scenariusze. Teraz, przebudzony, wchodzi na wzgórze, po drodze mijając kuszące kwiaty, „rozkwitłe w całej swej krasie, zionące upojną wonią z głębi zwojów”. Wchodzi, ale właściwie co chce tam zobaczyć? Wprawdzie doszedł już do pewnych wniosków, racjonalizując sobie wypadki z wizji ${ }^{48}$, ale przecież nie wie, co ujrzy na otoczonym różami wzgórzu. Zmierza tam dlatego, że popycha go urwana wizja senna, którą pragnie zakończyć. Siła noweli tkwiłaby więc w tym, że bohater nie budzi się z oddechem ulgi, by odsunąć od siebie niepokojącą wizję senną i powrócić do zbawiennej rzeczywistości, ale uparcie dąży do rozwikłania tego, co go przeraża, sam zmierza ku spotkaniu z Realnością rzeczywistości swego pożądania. I doświadcza go z całą mocą, gdy zagląda do ogrodowej altany:

W ramach mirtu zarysowały się plecy i głowa kobiety. Krucze włosy miała uczesane w grecki węzeł, szyję ujmował wysoki kołnierz białej, kaszmirowej sukni á la Maria Stuart. Twarzy stąd nie widziałem, gdyż była odwrócona w przeciwną stronę. Lekkie przechylenie wstecz smukłej kibici nadawało jej wygląd rozkosznego marzenia, zapatrzenia się w dal, kontemplacji południa... Wstrzymałem się onieśmielony.

A może to kolejna, kojąca zasłona fantazji? Pożądanie podmiotu jest znów przesunięte i obsadzone na fantazmatycznym, estetycznie nienagannym obiekcie? Nic bardziej mylnego:

Gdy jednak przez dłuższy czas nie poruszyła się z miejsca, przemogłem się i przebywszy ostatni przegub wężownicy, stanąłem we wnętrzu altany.

Jedno spojrzenie wydarło mi z piersi okrzyk zgrozy. Na tle mirtów, wciśnięte w szerokie, trzcinowe krzesło z poręczami siedziały zwłoki młodej kobiety w stadium daleko posuniętego rozkładu. Twarz o szlachetnym, podłużnym owalu przedrążyły już wstrętne, wygniłe jamy. Na strupieszałym palcu lewej ręki zwisłej z poręczy krzesła rozrzucał mokre blaski szmaragdowy sygnet. Był otwarty; odchylone wieczko ukazywało wgłębienie wielkości naparstka, wnętrze było puste...

Zapach róż, niezidentyfikowana początkowo woń trupa, rozrastające się znamię na twarzy kobiety, a wreszcie inicjujący nowelę aforyzm - dla wszystkich tych signifiants naczelnym znaczonym okazuje się śmierć. Pożądanie narratora, które narodziło się już pierwszego dnia spędzonego pod murem, było więc pożądaniem tego, co w noweli najbardziej erotyczne i uwodzicielkie - Tanatosa. Bohater podejmował pewną grę w zbliżanie się i oddalanie (maskowanie) tego pragnienia, by ostatecznie skonfrontować się z nim w całej porażającej Realności. A więc i róże, piękne, odurzające i zachęcające do podtrzymywania fantazmatycznych ekstaz rosły w przestrzeni śmierci. Może właśnie dlatego:

${ }^{48}$ Bohater tuż po ostatnim przebudzeniu tłumaczy sobie całą sytuację retrospekcją, której doświadczył motywowany chusteczką kobiety. Dokonuje błyskawicznej dedukcji i uświadamia sobie, że zajście z wizji miało miejsce na kilka dni przed jego pierwszym pojawieniem się pod murem. 
Niepodobna przesadzić wskazując na tragikomiczne przeciwieństwa, jakimi naznaczony jest dramat śmierci nieskończenie odgrywany między ziemią a niebem, i jest oczywiste, że nie można sparafrazować tego szyderczego pojedynku inaczej niż wprowadzając - nie tyle w charakterze sentencji, co dokładniej jako strząśniętą z pióra plamę - ów odpychający frazes: ż e m i ł o ś ć $\mathrm{m}$ a $\mathrm{z}$ a p a $\mathrm{ch}$ ś $\mathrm{m}$ i e $\mathrm{r} \mathrm{c}$ i. Wydaje się $\mathrm{w}$ istocie, że pożądanie nie ma nic wspólnego z idealnym pięknem, czy też - ściślej - że istnieje wyłącznie po to, by brukać i pozbawiać świeżości owo piękno, które dla tylu posępnych i statecznych umysłów jest tylko granicą, i m p e r a t y w e m k a t e g o r y c z n y m. Najbardziej zachwycający kwiat należałoby przedstawić sobie nie - w duchu paplaniny natchnionych poetów - jako mniej czy bardziej banalne uosobienie angielskiego ideału, lecz, całkiem przeciwnie, jako obsceniczne i jaskrawe świętokradztwo ${ }^{49}$.

Lektura rozkoszy podmiotu noweli już prawie dobiegła końca. Prawie. Zostało bowiem jeszcze coś, co nie pozwala czytelnikowi odłożyć tekstu. Oto finalny fragment opowiadania: „Ze wszechstron [!] zionęły gorączką jakieś olbrzymie, pracowite dysze, wstrzykiwały fale ognia opętane tłocznie. Jakieś straszne, spiekłe usta rozchyliły czarne wargi i pragną, pragną, pragną... Szaleją róże, purpurowe róże... A wśród orgii róż, wśród rozpusty róż ta duszna, trupia woń...”. Wizja na wskroś taediogenna. Infernalna przestrzeń i rozwarte usta trupa, które jednak trwają w „pozorze życia” przez nieskończone, erotyczne pragnienie ${ }^{50}$. Podmiot noweli, co starałam się wykazać, pożądał erotyzmu śmierci. Czego zaś pragną wstrętnie i uwodzicielsko rozchylone usta? Być może (a jest to tylko hipoteza) pragną właśnie życia. Być może te usta wychylają się ku czytelnikowi, ku erotycznej, choć zapewne niewolnej od obrzydzenia rozkoszy lektury, będącej zachwytem dla życia w jego najbardziej odurzającym aspekcie - śmierci. Można by teraz zauważyć (abstrahując od dzisiejszego statusu intencji autorskiej), że pozostaje to w pewien sposób po myśli Stefana Grabińskiego (cytowanej we wstępie niniejszego tekstu), jest to w końcu przejaw tak ważnego dla niego wielkiego zdumienia nad życiem, nad tym, co w samym życiu „życiowe” aż do jego granic. A jest to zdumienie być może nawet bardziej uderzające.

W 1918 roku recenzujący publikację tomu Na wzgórzu róż Henryk Salz odnotowal, że był świadkiem, jak „,cztery inteligentne osoby brały ją do ręki i po przeczytaniu kilku stron odkładały $[\ldots]$ z miną, jakby łyknęły octu" ${ }^{\text {". }}$. Skrzywienie zacnych recenzentów to najlepszy dowód na siłę oddziaływania tekstu. A proponowana tu interpretacja? W odnalezionym niedawno i opublikowanym fragmencie prozy poetyckiej Stefana Grabińskiego ${ }^{52}$ pojawia się historia Mistrza, który wykuwa z granitu doskonale piękne figury. Razu pewnego zjawia mu się wstrętny karzeł, również wycinający w kamieniu kształty, w których Mistrz, początkowo nie wierząc, dopiero po pewnym czasie dopatruje się realizacji własnych pomysłów. Tyle że z „odmiennego punktu widzenia”. Karzeł zwraca uwagę Mistrzowi, że jego idealnie piękne twory kryją za swą fasadą możliwość dostrzeżenia w nich czegoś innego, zniekształconego, niepokojącego. Samo dzieło Mistrza zakłada już istnienie karła, który przechwyci jego intencje i „dłutem nędznej ręki” uformuje swój kształt. Czy twór karła może okazać się interesujący? Możliwe, że tak, jak interesujące pozostają rozchylające się czarne wargi „strasznych, spiekłych ust”.

49 G. Bataille, Mowa kwiatów, tłum. K. Matuszewski, „Ogród” 1991, nr 3, s. 242.

50 "Pozór życia w martwym jest nieskończoną ohydą we wstrętności”. K. Rozenkranz, Ästhetik des Häßlichen, Darmstadt 1979, s. 313. Za: W. Menninghaus, Wstręt. Teoria i historia, tłum. G. Sowiński, Kraków 2009, s. 176.

${ }^{5}$ H. Salz, Na wzgórzu róż, „Nowy Głos Przemyski” 1918, nr 53, s. 2.

52 Mowa tu o noweli Ironia - zob. Maska śmierci, s. 328-330. 


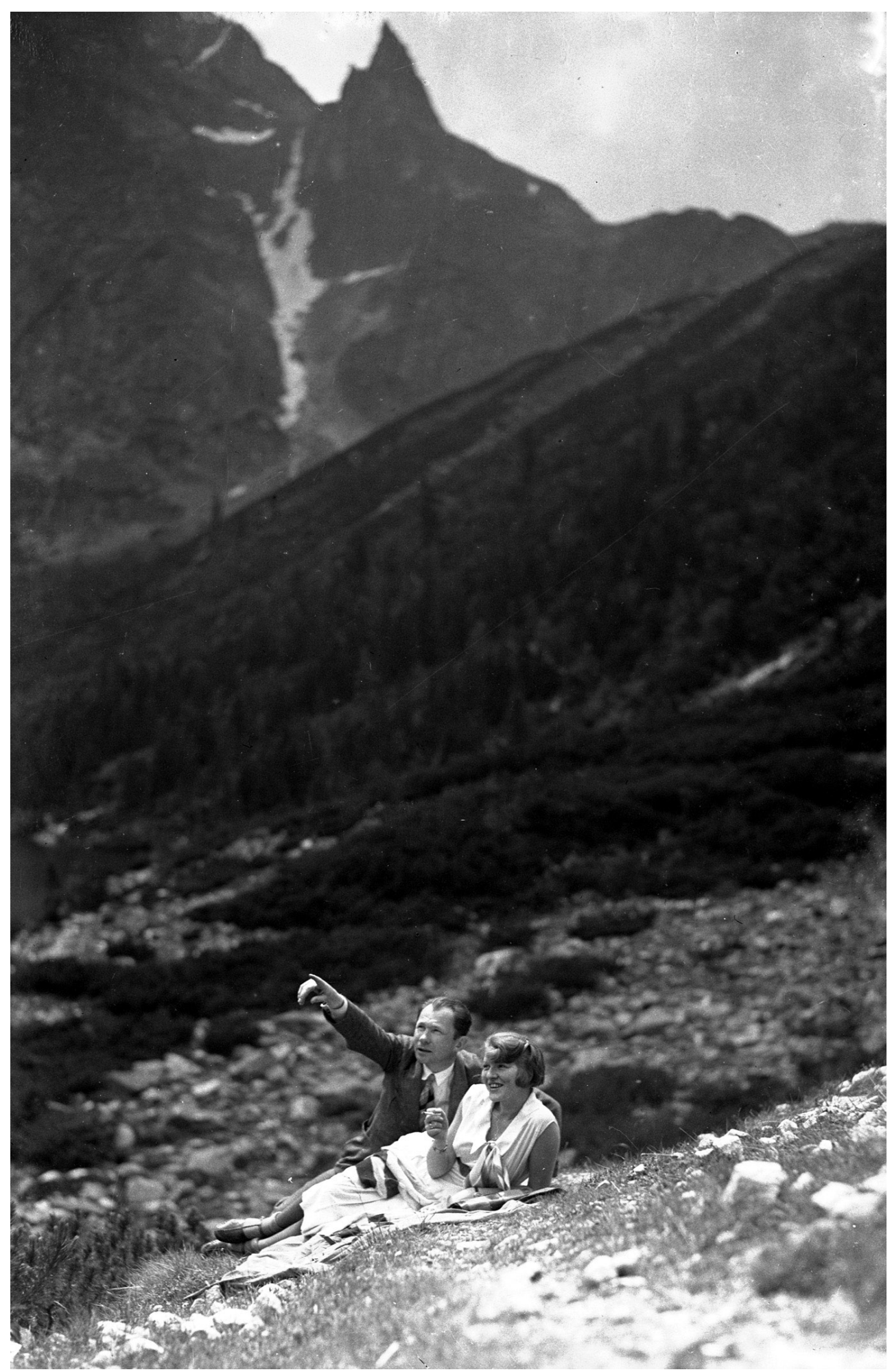

Józef Aleksander

Gałuszka (1893-1939)

z żoną Edytą nad Morskim

Okiem, bliski kolega po

piórze Grabińskiego, bohater

recenzji pisarza. Ze zbiorów

Narodowego Archiwum

Cyfrowego

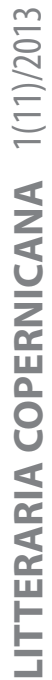




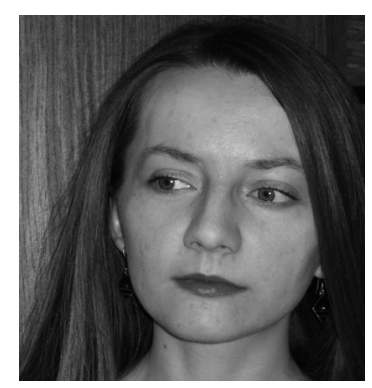

\section{Anna Kruszczyńska}

Anna Kruszczyńska - doktorantka w Zakładzie Literatury Młodej Polski i Dwudziestolecia Międzywojennego Uniwersytetu Mikołaja Kopernika w Toruniu. Zajmuje się literaturą Młodej Polski (szczególnie obrazem prasłowiańszczyzny, Biblią w literaturze, twórczością poetek tego okresu) i folklorem tradycyjnym. Wybrane artykuły: „Jam jest Głos Wołajacy" - "Chrzciciel" Jadwigi Marcinowskiej; Od ciała pierwotnego do astrala zwulkanizowanego (Antoni Lange "Miranda"); „Orzeł oślepły” Marii Grossek-Koryckiejsymbolika katastrofizmu i odrodzenia; Unde malum? - "Siostra" Małgorzaty Saramonowicz. 